\title{
Disposition of lipids in the postprandial state
}

\author{
BY CHRISTINE M. WILLIAMS* \\ School of Biological Sciences, University of Surrey, Guildford GU2 $5 X H$
}

\section{Utilisation des lipides à l'état postprandial}

\begin{abstract}
RÉSUMÉ
Récemment, il est apparu un intérêt renouvelé pour la régulation du métabolisme postprandial des lipides, pour les facteurs qui influencent l'utilisation des lipides après la consommation des repas. Cet intérêt est la conséquence de ce qu'il a été montré que les lipoprotéines riches en triacylglycérol, les chylomicrons et les VLDL sont impliquées dans la pathogenèse de la maladie coronarienne. Les chylomicrons dérivés de l'alimentation sont les plus importants responsables de l'augmentation du triacylglycérol après les repas, avec moins de $\mathbf{2 0} \%$ de l'augmentation du triacylglycérol mis au compte des augmentations de l'apolipoprotéine B-100 contenant des VLDL. Les résultats actuels suggèrent que l'augmentation précoce des VLDL après les repas est due à l'altération de l'élimination de ces particules, du fait de l'influx des chylomicrons qui sont les substrats préférentiels pour la lipoprotéine lipase (LPL). Il est possible que les hormones de l'axe entéro-insulaire, l'insuline et le polypeptide insulinothropique dépendant du glucose (GIP), participent à un mécanisme homéostatique sensible à l'alimentation, qui régule l'utilisation des lipides en réponse aux variations dans la prise des lipides dans l'alimentation. Ces deux hormones stimulent l'activité de la LPL et, il a été observé in vitro, que le GIP favorisait les actions lipolytiques de l'insuline. La co-sécrétion de ces hormones en réponse à l'ingestion des repas renforcera de ce fait le relargage d'acides gras non estérifiés (NEFA) à partir du triacylglycérol circulant. La démonstration que la sécrétion de GIP est modifiée par la quantité et le type de graisse de l'alimentation fournit un mécanisme potentiel par lequel l'évacuation du triacylglycérol peut être régulé en coordination en réponse à la charge de graisse dans l'alimentation.

Il est possible que le maintien d'un gradient de concentration de NEFA entre le plasma sanguin et l'adipocyte soit un composant important de la régulation normale de l'utilisation des lipides, puisqu'il a été montré que l'absence de captation de NEFA et l'accumulation de NEFA à la surface endothéliale entraînaient le relargage et l'inactivation de la LPL. Un fragment du complément C3, identifié comme C3 des Arg, s'est révélé être synthétisé dans le tissu adipeux, et a été désigné sous l'appellation de protéine stimulant l'acylation (ASP) en raison de sa capacité à stimuler in vitro la synthèse du triacylglycérol dans les adipocytes et dans les fibroblastes de la peau. L'ASP stimule l'estérification des acides gras en triacylglycérol en stimulant de captation du glucose de l'adipocyte par la translocation des transporteurs du glucose, et en stimulant l'étape régulatoire du taux dans la synthèse du triacylglycérol à l'acyltransférase diacylglycérol. Chez les sujets humains, l'administration d'une charge de graisse (mais non de glucose)

\footnotetext{
* Present address: The Hugh Sinclair Unit of Human Nutrition, Department of Food Science and Technology, University of Reading, Whiteknights, PO Box 228, Reading.
} 
par voie orale mène à une augmentation des concentrations d'ASP circulante dans le même temps que se produit l'augmentation des concentrations de triacylglycérol. L'absence de la captation de NEFA stimulée pas l'ASP, et d'autres mécanismes qui réduisent les concentrations de NEFA intracellulaires (comme dans l'inhibition de la lipase sensible aux hormones) peut conduire à l'accumulation de NEFA dans la circulation postprandiale et à la poursuite de l'inhibition de l'hydrolyse du triacylglycérol.

La quantité et le type des graisses dans un repas, aussi bien que dans le type l'alimentation, influence l'étendue et la durée de la réponse du triacylglycérol postprandial, avec des réponses lipémiques observées plus souvent chez les sujets plus âgés, et chez les hommes que chez les femmes. En relation avec les effets des acides gras spécifiques, les acides gras polyinsaturés à chaîne longue $n-3$ ont le plus grand potentiel pour réduire les concentrations de triacylglycérol aussi bien dans le jeûne qu'après les repas, bien que les mécanismes et les loci de leurs effets n'aient pas été totalement élucidés. Comme la plupart des études sur les réponses des métabolites et des hormones à des repas standard ont été menées sur des sujets après le jeûne de la nuit (à jeun), on connaît peu de choses sur la forme et la nature des réponses postprandiales du triacylglycérol et des NEFA dans des conditions plus physiologiques dans lesquelles deux ou trois repas sont pris à la suite. Des résultats récents suggèrent que le triacylglycérol consommé dans un seul repas n'entre pas en totalité dans la circulation systémique dans la période qui suit immédiatement le repas (de 2 à 5 heures), mais que des quantités significatives restent dans la lumière intestinale ou dans l'entérocyte, jusqu'à ce que la consommation du repas suivant entraîne l'entrée rapide de ce triacylglycérol 'de réserve'. L'impact de cette entrée précoce de triacylglycérol ingéré auparavant sur les réponses postprandiales lipémiques et des NEFA des repas suivants n'a pas été totalement étudié, et il est possible qu'il ait des implications considérables sur notre appréhension du métabolisme du triacylglycérol des chylomicrons et des VLDL.

Interest in the role of triacylglycerol-rich lipoproteins (TRL; chylomicrons (CM) and VLDL) in the pathogenesis of coronary artery disease (CAD) has been stimulated by recent evidence that an exaggerated postprandial triacylglycerol response to fatcontaining meals is a significant risk factor for CAD (Simpson et al. 1990; Groot et al. 1991; Patsch et al. 1992). This phenomenon is sometimes referred to as 'triacylglycerol intolerance' because, like the glucose intolerance of diabetes, it is most clearly demonstrated in response to an oral challenge. The mechanisms which may underlie this association include the increased production of potentially atherogenic lipoproteins (Sethi et al. 1993; Griffin \& Packard, 1994) and increased thrombotic tendency (Miller et al. 1991) which have been demonstrated in subjects with elevated triacylglycerol levels.

Recognition of the involvement of TRL in the pathogenesis of CAD has re-focused attention also on the mechanisms involved in the normal regulation of circulating triacylglycerol concentrations. The aim of the present review is to consider recent findings on factors which influence lipid disposition following meal consumption. In particular, the hormonal and nutritional determinants of postprandial lipid disposition, and the contribution of intestinal $v$. hepatic TRL to increases in triacylglycerol concentrations in the postprandial state, will be considered. 
Similarities in size and density between large VLDL (VLDL1) and CM, preclude the complete separation of these particles by ultracentrifugation. However, recent developments in immuno-affinity technology and the production of specific antibodies to apolipoprotein B-100 (apo B-100) have enabled the development of immuno-affinity procedures which allow separation of apo B-100-containing VLDL, from apolipoprotein B-48-containing CM. Using this approach, Cohn et al. (1993) estimated that over $80 \%$ of the postprandial increase in triacylglycerol is due to the influx of intestinally-derived CM. In this study a small increase in large VLDL was seen in the first few hours after the meal, but this was not sustained and levels fell below baseline within $6 \mathrm{~h}$ of meal consumption. Essentially similar findings were reported by Schneeman et al. (1993) who used a monospecific antibody to apo B-100 to separate CM and VLDL. The increase in VLDL in the early postprandial period (2-3 h) may be due to enhanced hepatic secretion, or delayed removal, of VLDL due to competition from gut-derived CM. Karpe et al. (1993) measured apo B-48 and apo B-100 concentrations in Sf (Svedberg flotation which characterizes particles according to their flotation under defined conditions of centrifugal force, density and temperature) 60-400 (large VLDL and CM) and Sf 20-60 (small VLDL and CM remnants) lipoprotein fractions and concluded that the postprandial rise in apo B-100 in the Sf $60-400$ fraction was probably due to competition from apo B-48-containing particles. This conclusion was supported by their observation that the concentration of apo B-100 in the Sf 20-60 fraction fell postprandially, probably due to reduced generation of small VLDL particles which would otherwise arise from the hydrolysis of the precursor large VLDL (Karpe et al. 1993). More direct evidence for CM-induced inhibition of VLDL-triacylglycerol clearance was obtained by Potts et al. (1991) who measured arterio-venous differences of CM and VLDL-triacylglycerol across the abdominal adipose tissue wall before and for $6 \mathrm{~h}$ after meal consumption. A marked increase in CM triacylglycerol extraction was seen within 60 min of meal consumption and was associated with a corresponding reduction in VLDL-triacylglycerol removal. These findings support the view that the two particles are competing for a common saturable removal mechanism, i.e. lipoprotein lipase ( $E C$ 3.1.1.34; LPL)-mediated triacylglycerol hydrolysis, and suggest that the early postprandial rise in VLDL represents VLDL accumulation rather than entry of newly secreted particles. However, the observation that LPL does not become saturated until triacylglycerol concentrations reach approximately $5 \mathrm{mmol} / \mathrm{l}$ (Brunzell et al. 1973), and that in adipose tissue suppression of VLDL removal occurs before CM concentrations have reached a plateau (Potts et al. 1991), suggest the possibility of other more specific mechanisms which determine preferential hydrolysis of CM-triacylglycerol compared with VLDLtriacylglycerol.

\section{THE REGULATORY ROLE OF ENDOCRINE AND PARACRINE FACTORS}

LPL is the key regulatory enzyme in lipid disposition. It is synthesized in tissue parenchyma cells and is exported to the capillary endothelium where it is responsible for the hydrolysis of CM- and VLDL-triacylglycerol, with preference for $s n-1$ - and $s n-2-$ located fatty acids (Eckel, 1989). Although it has long been established that this enzyme responds rapidly to changes in nutritional state (Robinson, 1970; Nilsson-Ehle et al. 1980), the hormonal regulation of LPL in the fed and fasted state remains incompletely 
understood. Much circumstantial evidence had accumulated by the 1970 s which suggested that LPL was an insulin-dependent enzyme, but it was not until the 1980s that Sadur \& Eckel (1982), using the euglycaemic clamp technique together with sequential adipose tissue biopsy, showed that human adipose tissue LPL is stimulated two- to threefold by insulin. The measurement of glycerol production across abdominal adipose tissue in vivo allowed Frayn et al. (1994) to estimate LPL action in response to meal ingestion. They showed a threefold rise in LPL-mediated glycerol production, with a linear increase with time up to $6 \mathrm{~h}$ after the meal (Frayn et al. 1994). This closely corresponds with the time-course of changes in triacylglycerol clearance reported by Coppack et al. (1992) using the same experimental model. In normal subjects the peak triacylglycerol clearance occurred $5 \mathrm{~h}$ after consumption of a mixed meal (Coppack et al. 1992), which is in accord with insulin-infusion studies which show maximal insulin stimulation of LPL between 4 and $6 \mathrm{~h}$ following insulin infusion (Yki-Jarvinen et al. 1984).

Although it is clear that insulin is important in mediating postprandial changes in LPL activity, it is not clear to what extent insulin participates in a coordinated homeostatic mechanism for regulating circulating triacylglycerol concentrations in response to fluctuations in dietary fat intake, in a similar manner to its role in glucose homeostasis. A dose-response relationship between meal fat content, postprandial plasma triacylglycerol levels and post-heparin LPL activity has been shown, but in the same study there was found to be no effect of meal fat content on postprandial insulin response (Murphy et al. 1995).

The gastrointestinal hormone, glucose-dependent insulinotrophic polypeptide (GIP), whose major action is to potentiate insulin secretion following meal consumption, has been suggested as a possible effector of dietary-fat-induced alterations in LPL activity. It has been shown that GIP secretion is influenced by both acute (Kwasowski et al. 1985) and chronic intakes of dietary fat (Morgan et al. 1988a,b), and in rats GIP administration leads to increased clearance of CM (Ebert et al. 1991). In vitro studies of adipose-tissue explants have shown GIP to promote modest LPL stimulation and also to potentiate the action of insulin on adipose-tissue LPL in vitro (Eckel et al. 1979; Knapper et al. 1995). Thus, GIP, along with insulin, may act as the diet-sensitive effector of a homeostatic loop mechanism whereby dietary fat intake and triacylglycerol disposition are coordinately regulated.

Regulation of triacylglycerol removal from plasma may be achieved also through the actions of a locally produced hormone, termed acylation-stimulating protein (ASP). ASP is a $14 \mathrm{kDa}$ plasma protein (Cianflone et al. 1989a), originally shown to be a component of normal human serum which caused potent stimulation of lipogenesis in skin fibroblasts and adipose tissue (Cianflone et al. 1988). It is now known that the adipocyte can synthesize three proteins necessary for the formation of ASP. Isolation and characterization of ASP showed the amino acid sequence of the active peptide to be homologous with that of a fragment of complement $\mathrm{C} 3$, complement $\mathrm{C} 3 \mathrm{a}$, although it was found later that the active form of ASP was in fact C3a des Arg (Baldo et al. 1993). It was shown that two other proteins necessary for the proteolytic cleavage of $\mathrm{C} 3 \mathrm{a}$ des Arg from the precursor $\mathrm{C} 3$ were also components of the complement pathway, and these complement factors B and D were also synthesized in adipose tissue. ASP causes a pronounced increase in intracellular esterification of fatty acids into triacylglycerol in human fibroblasts and adipocytes (Cianflone et al. 1988) and is approximately five times more 


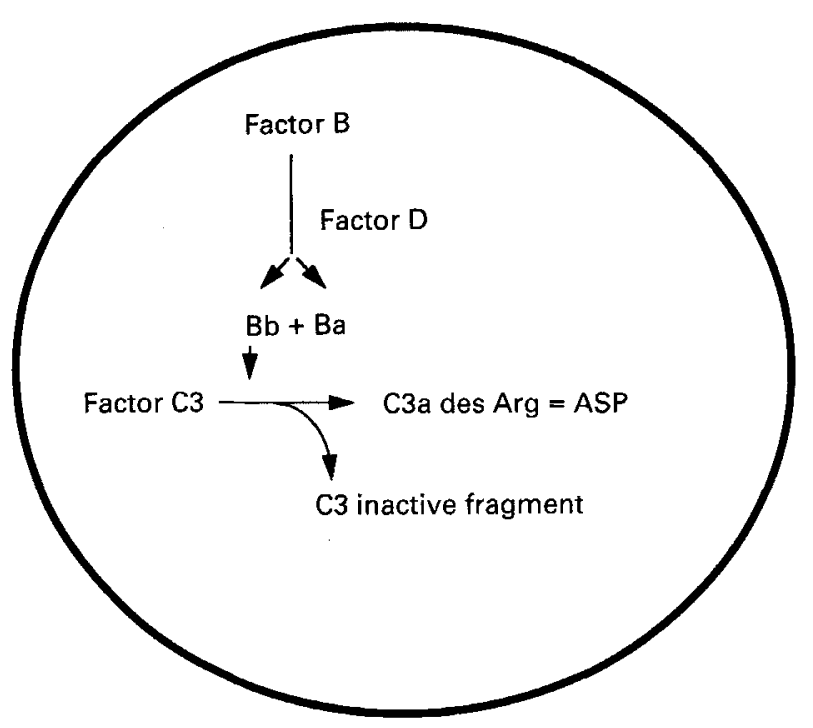

Fig. 1. The role of complement factors B, D and C in the generation of C3a des Arg (ASP) in the adjpocyte. Proteolytic cleavage of factor $\mathrm{B}$ by factor $\mathrm{D}$ leads to the production of two fragments, $\mathrm{Bb}$ and $\mathrm{Ba}, \mathrm{Bb}$ acts on complement factor C3 with the production of the active peptide C3a des Arg (From Baldo et al. 1993).

potent than insulin in this respect. ASP does not stimulate fatty acid transport directly but causes translocation of glucose transporters from intracellular vesicles to the cell surface (Germinario et al. 1993) and stimulation of the rate-limiting enzyme of triacylglycerol synthesis, diacylglycerol acyltransferase $(E C$ 2.3.1.20; Yasruel et al. 1991). Stimulation of the ASP cascade (Fig. 1) may be provoked by the attachment of TRL to LPL, although the precise mechanisms involved have not been elucidated. Evidence that oral fat ingestion leads to the formation of ASP is supported by measurement of postprandial ASP concentrations, which increase by over $50 \%$ in response to fat feeding, with the increase occurring over the same time-course as the increase in triacylglycerol concentration. Conversely, glucose feeding had no effect on plasma ASP concentrations (Cianflone et al. 1989b).

ASP may act in a complementary manner with LPL, ensuring the maintenance of a non-esterified fatty acid (NEFA) concentration gradient within adipose tissue, which enables the rapid and continued uptake of NEFA released by the action of LPL on CM and VLDL (Fig. 2). It would be predicted that an absence or reduced response to ASP will result in reduced NEFA uptake into adipose tissue. Failure in the NEFA-removal mechanism and accumulation of NEFA at the endothelial surface may have adverse consequences for triacylglycerol hydrolysis and circulating triacylglycerol homeostasis, since the binding of LPL to the endothelium is thought to be weakened by local accumulation of fatty acids released following triacylglycerol hydrolysis. LPL bound to heparin-agarose is displaced by high concentrations of fatty acids and this effect can be abolished by the addition of albumin (Peterson et al. 1990). Individuals in whom the lipolytic system has been overloaded by infusions of lipid emulsions also show evidence of decreased endothelial binding of LPL (Olivecrona \& Bengsston-Olivecrona, 1990; Peterson et al. 1990) and similar findings are observed in adipocyte-cell culture systems 


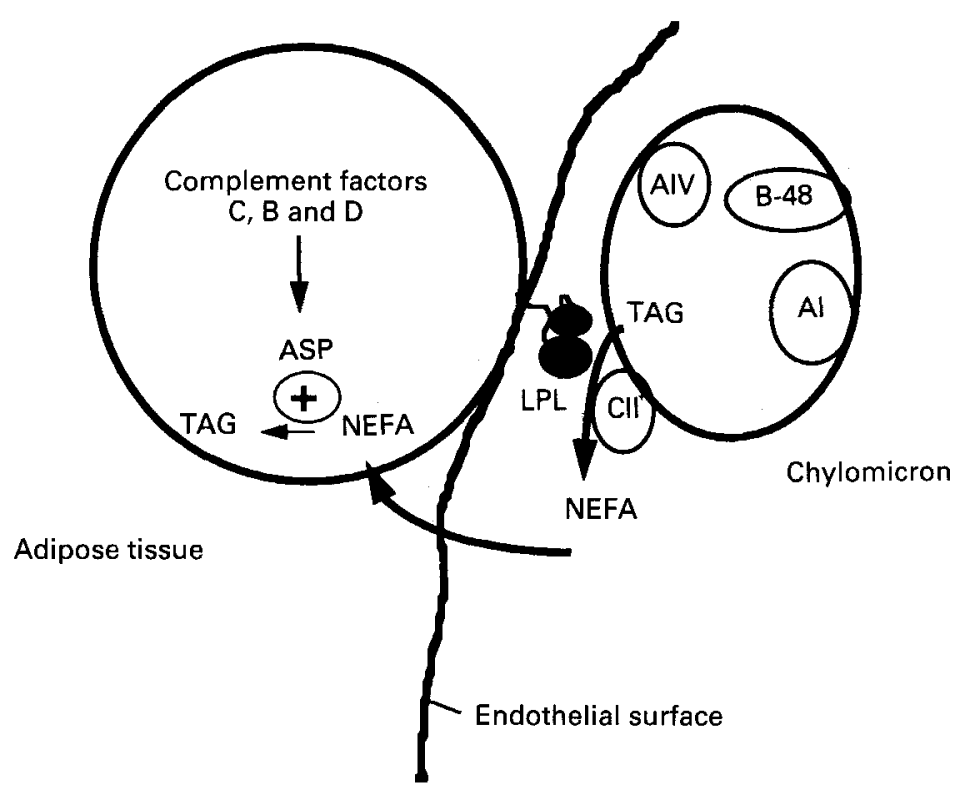

Fig. 2. A diagrammatic representation of the role of lipoprotein lipase (EC 3.1.1.34; LPL) and acylationstimulating protein (ASP) in the regulation of chylomicron triacylglycerol (TAG) hydrolysis and nonesterified fatty acid (NEFA) uptake into adipose tissue. AIV, apolipoprotein AIV; AI, apolipoprotein AI; CII, apolipoprotein CII; B-48, apolipoprotein B-48.

(Saxena et al. 1989). The correlation between postprandial dietary-derived fatty acids and circulating non-endothelially-bound LPL activity found in normal and hypertriacylglycerolaemic subjects, and the increase in unbound LPL which occurred in the postprandial circulation in these subjects provides strong evidence that there is NEFAinduced release of LPL in the period 3-9 h following meal consumption (Karpe et al. 1992).

The proportion of NEFA taken up by adipose tissue following the action of LPL has been estimated by Frayn et al. (1994) who showed that only 50-60\% of LPL-derived NEFA are removed by adipose tissue in the first $5 \mathrm{~h}$ after meal consumption. At later stages removal falls to levels less than $20 \%$ of total fatty acids (Frayn et al. 1994; Fig. 3). These findings suggest, therefore, that saturation of the NEFA-removal mechanism may commonly occur following consumption of fat-containing meals, with consequent adverse effects on the hydrolysis and removal of TRL. The fact that this is more likely to occur with the feeding of high-fat meals (Fig. 4) is evident from studies which show flattening of the normal inverse-bell-shaped response curve when high-fat meals are fed compared with low-fat meals (Griffiths et al. 1994; Murphy et al. 1995).

\section{NUTRITIONAL FACTORS}

Given the pre-eminent role of CM particles in postprandial lipid metabolism, it is to be expected that nutritional factors will play a major part in determining the extent and rate of lipid disposition in the postprandial phase. 


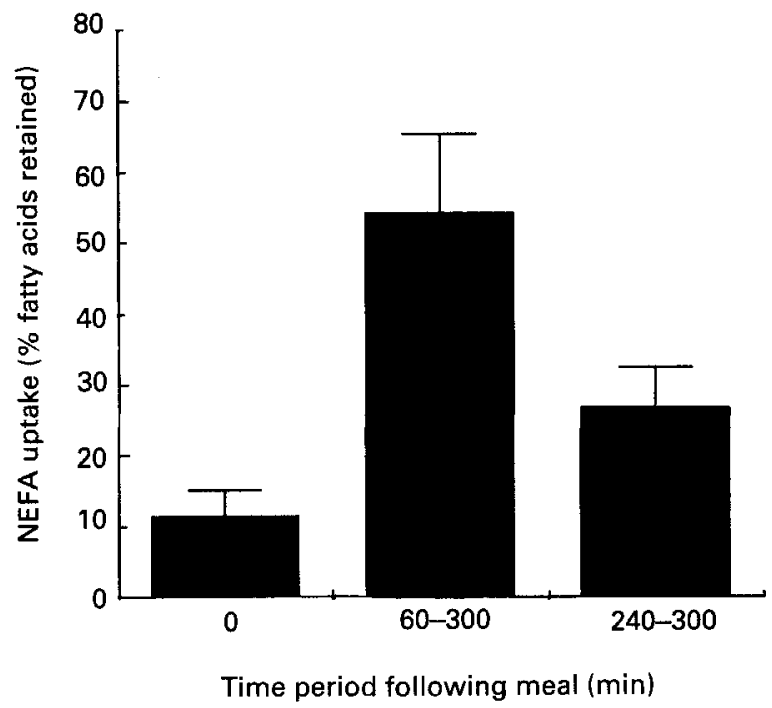

Fig. 3. Non-esterified fatty acid (NEFA) uptake (\% fatty acids retained) into subcutaneous abdominal adipose tissue during fasting $(0 \mathrm{~min})$, and between the periods 60 and 300 and 240 and $300 \mathrm{~min}$ postprandially (adapted from Frayn et al. 1994).

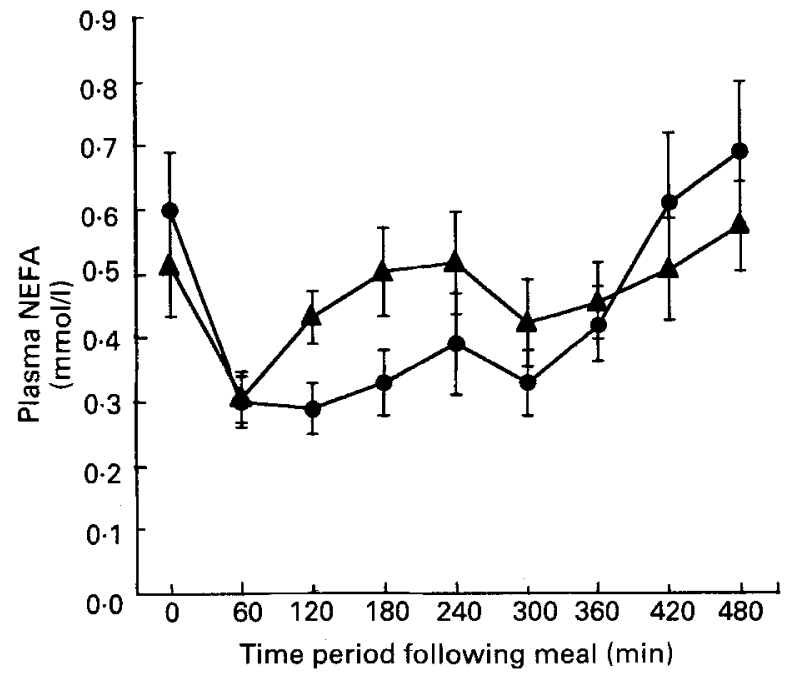

Fig. 4. Postprandial non-esterified fatty acid (NEFA) responses to low $(20 \mathrm{~g} ; \mathbf{O})$ and high $(80 \mathrm{~g} ; \boldsymbol{\Delta})$ fat meals containing identical amounts of protein and carbohydrate in young male subjects. Values are means with their standard errors represented by vertical bars for ten subjects (Murphy et al. 1995).

Cohn et al. (1988a) showed a progressive increase in plasma triacylglycerol response to increasing volumes of cream in healthy volunteers. A similar dose response was observed when mixed meals of identical carbohydrate and protein content but increasing amounts of fat were fed to young male subjects (Murphy et al. 1995). In this study the mean 
incremental areas under the plasma triacylglycerol response curves following consumption of meals containing 20, 40 or $80 \mathrm{~g}$ fat were 39 (SE 10), 56 (SE 19) and 79 (SE 18) min.mmol/l respectively. Although the higher fat intakes increased the plasma triacylglycerol response, the unit increase in triacylglycerol/g fat consumed decreased with increasing fat load, with values of $1.95,1.5$ and $1.0 \mathrm{~min} . \mathrm{mmol} / \mathrm{l}$ per $\mathrm{g}$ for the 20,40 and 80 $\mathrm{g}$ meals respectively. In these young healthy male subjects, given meals of varying fat contents after an overnight fast, there appears to be an efficient homeostatic mechanism which maintains circulating triacylglycerol concentrations within narrow limits despite wide variations in fat intake. The effects on triacylglycerol tolerance of varying degrees of insulin resistance and of defects in the GIP and ASP regulatory mechanisms have not been systematically studied, although it is known that triacylglycerol response to meals is increased with age and in male subjects as compared with female subjects (Cohn et al. $1988 \mathrm{~b}$ ). It has also been suggested that a failure in the normal response to ASP underlies the lipoprotein abnormalities of subjects with hyperapobetalipoproteinaemia (Cianflone et al. 1990), one of the commonest lipid disorders linked with increased risk of CAD. The adverse consequences of insulin resistance on triacylglycerol tolerance are illustrated by exaggerated triacylglycerol responses to fat-containing meals observed in some subjects with non-insulin-dependent diabetes mellitus (NIDDM) (Syvanne et al. 1993), although not all studies report differences between diabetic and control subjects (Chen et al. 1993). In some studies elevated postprandial triacylglycerol levels have only been reported in those subjects with raised fasting triacylglycerol concentrations (Lewis et al. 1991; Tan et al. 1995). For this reason, there is currently much debate as to the mechanisms underlying the exaggerated postprandial lipaemic response of the NIDDM subject, with the possibility of defects in the regulation of both VLDL secretion and LPL-stimulated clearance.

The consequences of sequential meal intake on circulating lipid homeostasis have only recently been studied, despite the fact that this is the normal pattern of daily food consumption in most human societies. Our present understanding of the nutritional and hormonal factors which influence lipid disposition in the postprandial state are largely based on measurements of substrate and hormone responses to single meals consumed following an overnight fast. More recently studies have been conducted in the non-fasted state and have followed metabolite responses to consecutive meals. A biphasic triacylglycerol and apo B-48 response to a mixed meal was observed in subjects given an evening meal following a standard lunch $5 \mathrm{~h}$ previously. An initial sharp increase in triacylglycerol and apo B-48 was seen 60 min after the meal, with a later more sustained rise at approximately $5 \mathrm{~h}$. Retinyl palmitate, which acts as a marker for dietary triacylglycerol, was given along with the evening test meal and showed only a single peak corresponding to the second peak of triacylglycerol and apo B-48. The early sharp triacylglycerol peak, which is not seen following an overnight fast, and the presence of apo B-48 but not retinyl palmitate in the early peak, led to the conclusion that the early peak represented entry of triacylglycerol from the lunch-time meal (Peel et al. 1993). These findings suggest that not all dietary fat ingested as part of a single meal enters the circulation immediately, but that some remains either in the gut lumen or in the enterocyte and that on subsequent meal ingestion this 'stored' fat is secreted into the systemic circulation. Support for this proposal was obtained from a study in which subjects were fed two consecutive meals, breakfast and lunch, consisting of foods with very different fatty acid compositions. It was observed that the fatty acid composition of 
the early triacylglycerol rise seen in response to the lunch was dominated by fatty acids from the breakfast meal rather than from the lunch itself (Fielding et al. 1994). This study also suggested that sequential meal consumption may have implications for the nature and pattern of the NEFA response to meal consumption. Unlike the inverse-bell-shaped NEFA response curve which is seen in response to a meal given following an overnight fast, Fielding et al. (1994) found an unexpected increase in NEFA in the first $2 \mathrm{~h}$ following lunch and, over this time period, the fatty acid composition of the NEFA corresponded to the fatty acid composition of the breakfast given $5 \mathrm{~h}$ before the lunch. These findings support the data described earlier which suggest that a significant proportion of NEFA released from CM are not taken up by adipose tissue but enter the circulation. They also illustrate the marked differences in NEFA kinetics which are likely to occur when consecutive meals rather than single meals are fed, and suggest likely consequences on circulating triacylglycerol clearance and hepatic VLDL synthesis.

Although meal fat content is a major determinant of the extent and duration of the increased triacylglycerol response to a fat-containing meal, animal and human studies have also shown that the fatty acid composition of a meal modulates postprandial triacylglycerol response (Groot et al. 1988; Levy et al. 1991; Zampelas et al. 1994). When mixed meals containing $40 \mathrm{~g}$ maize, fish or mixed oil were given in random order to young male subjects, the areas under the triacylglycerol response curves were found to be in the order: mixed $>$ maize $>$ fish. Notably the post-heparin LPL responses, measured $12 \mathrm{~h}$ after the meals were consumed, were found to be inversely related to the triacylglycerol response, with the highest activity found following the fish-oil meal. Faster clearance of polyunsaturated fatty acid (PUFA)-containing CM may be responsible for these findings, since in rats injection of CM obtained from PUFA-fed animals into recipient animals resulted in a markedly faster rate of clearance compared with $\mathrm{CM}$ from chow-fed animals (Levy et al. 1991).

Background dietary fatty acid composition may also modulate postprandial triacylglycerol responses to standard meals, and this effect appears to be independent of, and in addition to, any effect of the meal fatty acid composition. A number of studies have demonstrated reduced plasma triacylglycerol (Harris et al. 1988; Weintraub et al. 1988; Brown \& Roberts, 1991; Demacker et al. 1991; Williams et al. 1992) and CM remnant (Weintraub et al. 1988; Demacker et al. 1991) responses to standard meals when the PUFA content of the background diet is increased. This effect is most marked when the diet is enriched with $n-3$ long-chain PUFA from fish or fish oils (Weintraub et al. 1988). The mechanisms underlying the attenuated postprandial triacylglycerol rise seen when the diet is enriched with $n$-3 PUFA are the subject of some controversy. In vivo studies in humans (Nestel et al. 1984) and in vitro studies of animal hepatocytes (Ribeiro et al. 1991) have clearly shown reduced synthesis and secretion of VLDL-triacylglycerol, and apo $\mathrm{B}$ in response to fish oil. The marked attenuation in CM-triacylglycerol response seen in subjects whose diets are enriched with $n-3$ PUFA is thereby explained as a result of reduced competition between CM and VLDL for the active site of LPL. However, animal studies show that, in addition to effects of $n$-3 PUFA on hepatic VLDL synthesis, there is also marked stimulation of both adipose tissue (Groot et al. 1988; Levy et al. 1991) and skeletal muscle LPL (Herzberg \& Rogerson, 1989; Baltzell et al. 1991) on feeding fish oils. An increase in epididymal-adipose-tissue LPLmRNA, also, has been reported in animals (Murphy et al. 1993). In humans the possibility that effects of $n-3$ PUFA on fasting and postprandial triacylglycerol may be attributed to stimulatory 
effects of these fatty acids on the LPL enzyme is more controversial since only modest increases (Weintraub et al. 1988) or no increases (Nozaki et al. 1991) in post-heparin LPL activity have been observed in subjects fed on fish-rich diets or given $n-3$ PUFA supplements. The observation that no differences in clearance of an intravenously administered artificial emulsion were observed in subjects given fish-oil supplements for 4 weeks (Harris \& Muzio, 1993) provides support for the view that the likely locus for effects of $n$-3 PUFA is either hepatic VLDL synthesis or the intestinal processing of CM particles themselves (Murthy et al. 1992). Because of the limitations of post-heparin LPL as a measurement of whole-body triacylglycerol-clearing capacity, further studies of tissue levels of LPL in humans are required before the role of hepatic and peripheral tissue modification of TRL metabolism by $n-3$ PUFA is fully understood.

\section{CONCLUSION}

Hormones of the entero-insular axis, notably insulin and GIP, play a central role in circulating triacylglycerol homeostasis by their actions on the enzyme LPL which regulates the hydrolysis of CM- and VLDL-triacylglycerol. The maintenance of a NEFA concentration gradient between blood plasma and the adipocyte is necessary to ensure continued removal and uptake of NEFA released by the action of LPL. A role for the complement fragment C3a des Arg (ASP) in this process has been proposed and further studies of the regulation of this pathway and its coordination by dietary triacylglycerol supply are needed. Diet has the capacity to modulate triacylglycerol response to fat-containing meals since both the amount and type of fat consumed influence the extent and duration of postprandial lipaemia. The mechanisms by which the type of meal fat modifies postprandial triacylglycerol response are not fully elucidated and require investigation of peripheral tissue and enterocyte metabolism at the cellular and molecular level. The impact of the timing of sequential meals, and the influence of meal macronutrient composition on the triacylglycerol and NEFA responses to sequential meals also require study, in view of evidence for modification of postprandial lipid responses by previous meal intake. The gut may play an important role in lipid homeostasis, with modifications in lipid absorption and enterocyte CM synthesis and secretion acting as likely loci for effects of diet on postprandial triacylglycerol metabolism.

\section{REFERENCES}

Baldo, A., Sniderman, A. D., St-Luce, S., Avramoglu, R. K., Maslowska, M., Hoang, B., Monge, J. C., Bell, A., Mulay, S. \& Cianflone, K. (1993). The adipsin-acylation stimulating protein system and regulation of intracellular triglyceride synthesis. Journal of Clinical Investigation 92, 1543-1547.

Baltzell, J. K., Wooten, J. T. \& Otto, D. A. (1991). Lipoprotein lipase in rats fed fish oil: apparent relationship to plasma insulin levels. Lipids 26, 289-294.

Brown, A. J. \& Roberts, D. C. K. (1991). Moderate fish oil intake improves lipemic response to a standard fat meal. A study in 25 healthy men. Arteriosclerosis and Thrombosis 11, 457-466.

Brunzell, J. D., Hazzard, W. R., Porte, D. \& Bierman, E. L. (1973). Evidence for a common saturable removal mechanism for chylomicrons and very low density lipoproteins in man. Journal of Clinical Investigation 52, 1578-1585.

Chen, Y.-D. I., Swami, S., Skowronski, R., Coulston, A. M. \& Reaven, G. M. (1993). Differences in postprandial lipemia between patients with normal glucose tolerance and noninsulin dependent diabetes mellitus. Journal of Clinical Endocrinology and Metabolism 76, 172-177. 
Cianflone, K., Maslowska, M. H. \& Sniderman, A. D. (1990). Impaired response of fibroblasts from patients with hyperapobetalipoproteinemia to acylation-stimulating protein. Journal of Clinical Investigation $\mathbf{8 5}$, $722-730$.

Cianflone, K., Rodriguez, M., Walsh, M. J., Vu, H. \& Sniderman, A. D. (1988). The effect of a plasma protein fraction on lipid synthesis in cultured skin fibroblasts from normals and patients with hyperbetalipoproteinemia. Clinical Investigation and Medicine 11, 99-107.

Cianflone, K., Vu, H., Baldo, W. B. \& Sniderman, A. (1989b). Metabolic response of acylation stimulating protein to an oral fat load. Journal of Lipid Research 30, 1727-1733.

Cianflone, K., Walsh, M. J., Vu, H., Gagnon, J., Sniderman, A. D. \& Rodriguez, M. A. (1989a). Purification and characterisation of ASP. Joumal of Biological Chemistry 265, 426-430.

Cohn, J. S., Johnson, E. J., Millar, J. S., Cohn, S. D., Milne, R. W., Marcel, Y. L., Russell, R. M. \& Schaefer, E. J. (1993). Contribution of apo B-48 and apo B-100 triglyceride-rich lipoproteins (TRL) to postprandial increases in the plasma concentration of TRL triglycerides in retinyl esters. Journal of Lipid Research 34, 2033-2040.

Cohn, J. S., McNamara, J. R., Cohn, S. D., Ordovas, J. M. \& Schaefer, E. J. (1988b). Postprandial plasma lipoprotein changes in human subjects of different ages. Journal of Lipid Research 29, 469-479.

Cohn, J. S., Noakes, T. D. \& Spinnler Benade, A. J. (1988a). Serum triglyceride responses to fatty meals: effects of meal fat content. American Journal of Clinical Nutrition 47, 825-827.

Coppack, S. W., Evans, R. D., Fisher, R. M., Frayn, K. N., Gibbons, G. F., Humphreys, S. M., Kirk, M. L., Potts, J. L. \& Hockaday, T. D. R. (1992). Adipose tissue metabolism in obesity: lipase action in vivo before and after a mixed meal. Metabolism 41, 264-272.

Demacker, P. M. N., Reijnen, I. G. M., Katan, M. B., Stuyt, P. M. J. \& Stalenhoef, A. F. H. (1991). Increased removal of remnants of triglyceride-rich lipoproteins on a diet rich in polyunsaturated fatty acids. European Journal of Clinical Investigation 21, 197-203.

Ebert, R., Nauck, M. \& Creutzfeldt, W. (1991). Effect of exogenous and endogenous gastric inhibitory polypeptide (GIP) on plasma triglyceride responses in rats. Hormones and Metabolic Research 23, 517-521.

Eckel, R. H. (1989). Lipoprotein lipase - a multifunctional enzyme relevant to common metabolic diseases. New England Journal of Medicine 320, 1060-1068.

Eckel, R. H., Fujimoto, W. Y. \& Brunzell, J. D. (1979). Gastroinhibitory polypeptide enhanced lipoprotein lipase activity in cultured preadipocytes. Diabetes $28,1141-1142$.

Fielding, B. A., Owen, R., Callow, J. \& Frayn, K. N. (1995). Origin of the early postprandial triacylglycerol peak. Proceedings of the Nutrition Society 54, 53A.

Frayn, K. N., Shahid, S., Hamlani, R., Humphreys, S. M., Clark, M. L., Fielding, B. A., Boland, O. \& Coppack, S. W. (1994). Regulation of fatty acid movement in human adipose tissue in the postabsorptiveto-postprandial transition. American Journal of Physiology 266, E303-E317.

Germinario, R., Sniderman, A. D., Manuel, S., Pratt, S., Baldo, A. \& Cianflone, K. (1993). Coordinate response of triacylglycerol synthesis and glucose transport by acylation stimulating protein. Metabolism: Clinical and Experimental 42, 547-580.

Griffin, B. A. \& Packard, C. J. (1994). Metabolism of VLDL and LDL sub-classes. Current Opinions in Lipidology 5, 200-206.

Griffiths, A. J., Humphreys, S. M., Clark, M. L., Fielding, B. A. \& Frayn, K. N. (1994). Immediate metabolic availability of dietary fat in combination with carbohydrate. American Journal of Clinical Nutrition 59, 53-59.

Groot, P. H. E., de Boer, B. C. J., Haddemen, E., Houtsmuller, U. M. T. \& Hulsmann, W. C. (1988). Effect of dietary fat composition on the metabolism of triacylglycerol-rich plasma lipoproteins in the postprandial phase in meal fed rats. Journal of Lipid Research 29, 541-551.

Groot, P. H. E., Van Stiphout, W. A. H. J., Krauss, X. H., Jansen, H., Van Tol, A., Van Ramshorst, E., Chin-On, S., Hofman, A., Cresswell, S. R. \& Havekes, L. (1991). Postprandial lipoprotein metabolism in normolipidemic men with and without Coronary Artery Disease. Arteriosclerosis and Thrombosis 11, $653-662$.

Harris, W. S., Connor, W. E., Alam, N. \& Illingworth, D. R. (1988). Reduction of postprandial triglyceridemia in humans by dietary n-3 fatty acids. Journal of Lipid Research 29, 1451-1460.

Harris, W. S. \& Muzio, F. (1993). Fish oil reduces postprandial triglyceride concentrations without accelerating lipid-emulsion removal rates. American Journal of Clinical Nutrition 58, 68-74.

Herzberg, G. R. \& Rogerson, M. (1989). The effect of dietary fish oil on muscle and adipose tissue lipoprotein lipase. Lipids 24, 351-353.

Karpe, F., Olivecrona, T., Walldius, G. \& Hamsten, A. (1992). Lipoprotein lipase in plasma after an oral fat load: relation to free fatty acids. Journal of Lipid Research 33, 975-984. 
Karpe, F., Steiner, G., Olivecrona, T., Carlson, L. A. \& Hamsten, A. (1993). Metabolism of triglyceride-rich lipoproteins during alimentary lipemia. Journal of Clinical Investigation 91, 748-758.

Knapper, J. M. E., Puddicombe, S. M., Morgan, L. M., Fletcher, J. \& Marks, V. (1995). Glucose dependent insulinotrophic polypeptide and glucagon-like peptide(7-36)amide: effects on lipoprotein lipase activity. Journal of Nutrition 124, 183-188.

Kwasowski, P., Flatt, P. R., Bailey, C. J. \& Marks, V. (1985). Effect of fatty acid chain length and saturation on gastric inhibitory peptide release in obese hyperglycaemic (ob/ob) mice. Bioscience Reports 5, 701-705.

Levy, E., Roy, C. C. R., Goldstein, R., Bar-On, H. \& Ziv, E. Z. (1991). Metabolic fate of chylomicrons obtained from rats maintained on diets varying in fatty acid composition. Journal of American College of Nutrition 10, 69-78.

Lewis, G. F., O'Meara, N. M., Solyts, P. A., Blackman, J. D., Iverius, P. H., Pugh, W. L., Getz, G. S. \& Polonsky, K. S. (1991). Hypertriglyceridemia in non-insulin dependent diabetes mellitus is an important predictor of postprandial lipid and lipoprotein abnormalities. Journal of Clinical Endocrinology and Metabolism 72, $934-944$.

Miller, G. J., Martin, J. C., Mitropoulos, K. A., Reeves, B. E. A., Thompson, R. L., Meade, T. W., Cooper, J. A. \& Cruickshank, J. K. (1991). Plasma factor VII is activated by postprandial triglyceridaemia irrespective of dietary fat composition. Atherosclerosis 86, 163-171.

Morgan, L. M., Hampton, S. M., Tredger, J. A., Cramb, R. \& Marks, V. (1988a). Modifications of gastric inhibitory polypeptide (GIP) secretion in man by a high-fat diet. British Journal of Nutrition 59, 373-380.

Morgan, L. M., Tredger, J. A., Hampton, S. M., French, A. P., Peake, J. C. F. \& Marks, V. (1988b). The effect of dietary modification and hyperglycaemia on gastric emptying and gastric inhibitory polypeptide (GIP) secretion. British Journal of Nutrition 60, 29-37.

Murphy, M. C., Isherwood, S. G., Sethi, S., Gould, B. J., Wright, J. W., Knapper, J. A. \& Williams, C. M. (1995). Postprandial lipid and hormone responses to meals of varying fat contents: modulatory role of lipoprotein lipase? European Journal of Clinical Nutrition 49, 579-588.

Murphy, M. C., Zampelas, A., Pudđicombe, S. M., Furlonger, N. P., Morgan, L. M. \& Williams, C. M. (1993). Pre-translational regulation of the lipoprotein lipase gene by dietary fatty acids in the rat. British Journal of Nutrition 70, 727-736.

Murthy, S., Albright, E., Mathur, S. N., Davidson, N. O. \& Field, F. J. (1992). Apolipoprotein B mRNA abundance is decreased by eicosapentaenoic acid in CaCo-2 cells. Arteriosclerosis and Thrombosis 12, 691-700.

Nestel, P. J., Connor, W. E., Reardon, M. F., Connor, S., Wong, S. \& Boston, R. (1984). Suppression by diets rich in fish oil of very low density lipoprotein production in man. Journal of Clinical Investigation 74, 82-89.

Nilsson-Ehle, P., Garfinkel, A. \& Schotz, M. C. (1980). Lipolytic enzymes and plasma lipoprotein metabolism. Annual Reviews of Biochemistry 49, 667-693.

Nozaki, S., Garg, A., Vega, G. L. \& Grundy, S. M. (1991). Postheparin lipolytic activity and plasma lipoprotein response to $\omega-3$ polyunsaturated fatty acids in patients with primary hypertriglyceridemia. American Journal of Clinical Nutrition 53, 638-642.

Olivecrona, T. \& Bengsston-Olivecrona, G. (1990). Lipoprotein lipase and hepatic lipase. Current Opinions in Lipidology 1, 222-230.

Patsch, J. R., Meisenbock, G., Hopferwieser, T., Muhlberger, V., Knall, E., Dunn, J. K., Gotto, A. M. \& Patsch, W. (1992). Relation of triglyceride metabolism and coronary artery disease. Arteriosclerosis and Thrombosis 12, 1336-1345.

Peel, A. S., Zampelas, A., Williams, C. M. \& Gould, B. J. (1993). A novel antiserum specific to apolipoprotein B-48: application in the investigation of postprandial lipidaemia in bumans. Clinical Science 85, 521-524.

Peterson, J., Bihain, B. E., Bengtsson-Olivecrona, G., Deckelbaum, R. J., Carpenter, Y. A. \& Olivecrona, T. (1990). Fatty acid control of lipoprotein lipase: A link between energy metabolism and lipid transport. Proceedings of the National Academy of Sciences, USA 87, 909-913.

Potts, J. L., Fisher, R. M., Humphreys, S. M., Coppack, S. W., Gibbons, G. F. \& Frayn, K. N. (1991). Peripheral triacylglycerol extraction in the fasting and post-prandial states. Clinical Science 81, 621-626.

Ribeiro, A., Magneney, M., Cardot, P., Loriette, C., Rayssiguier, Y., Chambaz, J. \& Bereziat, G. (1991). Effect of dietary fish oil and corn oil on lipid metabolism and apolipoprotein gene expression by rat liver. European Journal of Biochemistry 196, 499-507.

Robinson, D. S. (1970). The function of plasma triglycerides in fatty acid transport. In Comprehensive Biochemistry, vol. 18, pp. 51-116 [M. Florkin and E. H. Stotz, editors]. Amsterdam: Elsevier. 
Sadur, C. N. \& Eckel, R. H. (1982). Insulin stimulation of adipose tissue lipoprotein lipase. Journal of Clinical Investigation 69, 1119-1125.

Saxena, U., Witte, L. D. \& Goldberg, I. J. (1989). Release of endothelial cell lipoprotein lipase by plasma lipoproteins and free fatty acids. Journal of Biological Chemistry 264, 4349-4355.

Schneeman, B. O., Kotite, L., Todd, K. M. \& Havel, R. J. (1993). Relationship between the responses of triglyceride-rich lipoproteins in blood plasma containing apolipoprotein B-48 and B-100 to a fat-containing meal in normolipidemic humans. Proceedings of the National Academy of Sciences, USA 90, 2069-2073.

Sethi, S., Gibney, M. J. \& Williams, C. M. (1993). Postprandial lipoprotein metabolism. Nutrition Research Reviews 6, 161-183.

Simpson, H. S., Williamson, C. M., Olivecrona, T., Pringle, S., Maclean, J., Lorimer, A. R., Bonnefous, F., Bogaievsky, Y., Packard, C. J. \& Shepherd, J. (1990). Postprandial lipemia, fenofibrate and Coronary Artery Disease. Atherosclerosis 85, 193-202.

Syvanne, M., Vourinen-Markkola, H., Hilden, H. \& Taskinen, M.-R. (1993). Gemfibrozil reduces postprandial lipemia in non-insulin dependent diabetes mellitus. Arteriosclerosis and Thrombosis 13, 286-295.

Tan, K. C. B., Cooper, M. B., Ling, K. L. E., Griffin, B. A., Freeman, D. J., Packard, C. J., Shepherd, J., Hales, C. N. \& Betteridge, D. J. (1995). Fasting and postprandial determinants for the occurrence of small dense LDL species in non-insulin dependent diabetic patients with and without hypertriglyceridemia: the involvement of insulin, insulin precursor species and insulin resistance. Atherosclerosis 113, 273-287.

Weintraub, M. S., Zechner, R., Brown, A., Eisenberg, S. \& Breslow, J. L. (1988). Dietary polyunsaturated fats of the $\omega-6$ and $\omega-3$ series reduce postprandial lipoprotein levels. Journal of Clinical Investigation 82, 1884-1893.

Williams, C. M., Moore, F., Morgan, L. \& Wright, J. (1992). Effects of $n-3$ fatty acids on postprandial triacylglycerol and hormone concentrations in normal subjects. British Journal of Nutrition 68, 655-666.

Yasruel, Z. K., Cianflone, K., Sniderman, A. D., Rosenbloom, M., Walsh, M. \& Rodriguez, M. A. (1991). Effect of acylation stimulating protein on the triacylglycerol synthetic pathway of human adipose tissue. Lipids 26, 495-499.

Yki-Jarvinen, H., Taskinen, M.-R, \& Koivisto, V. A. (1984), Response of adipose tissue lipoprotein lipase activity and serum lipoproteins to acute hyperinsulinemia in man. Diabetologia 27, 364-369.

Zampelas, A., Murphy, M. C., Morgan, L. M. \& Williams, C. M. (1994). Postprandial lipoprotein lipase, insulin and gastric inhibitory polypeptide responses to test meals of different fatty acid composition: comparison of saturated, $n-6$ and $n-3$ polyunsaturated fatty acids. European Journal of Clinical Nutrition 48 , $849-858$ 